Meta

Journal des traducteurs

Translators' Journal

\title{
Transnationalism and Translation: Pseudo-Translation as a Newish Horizon in Translation Studies?
}

\section{Iris Guske}

Volume 60, numéro 2, août 2015

$60^{\mathrm{e}}$ anniversaire. Les horizons de la traduction : retour vers le futur $60^{\text {th }}$ Anniversary. Translation's Horizons: Back to the Future

60mo aniversario. Los horizontes de la traducción: regreso al futuro

URI : https://id.erudit.org/iderudit/1032890ar

DOI : https://doi.org/10.7202/1032890ar

Aller au sommaire du numéro

Éditeur(s)

Les Presses de l’Université de Montréal

ISSN

0026-0452 (imprimé)

1492-1421 (numérique)

Découvrir la revue

Citer ce document

Guske, I. (2015). Transnationalism and Translation: Pseudo-Translation as a Newish Horizon in Translation Studies? Meta, 60(2), 339-339.

https://doi.org/10.7202/1032890ar d'utilisation que vous pouvez consulter en ligne. 


\title{
Transnationalism and Translation: Pseudo-Translation as a Newish Horizon in Translation Studies?
}

\author{
IRIS GUSKE \\ Kempten School of Translation \& Interpreting Studies, Kempten, Germany \\ iguske@ifb-kempten.de
}

Using pseudo-translation as a framing device in his novel Everything Is Illuminated, J.S. Foer has transmitted linguistically a message that is usually conveyed editorially: the unreliability of reconstructing foreign events as a variable of transnational aporia, that is, the discontinuity of national memories.

While highlighting his conceptual and empathic distance from his Ukrainian family's history, the adoption of a purportedly inauthentic voice allowed Foer to be written by the text, his separate white and Eastern-European Jewish identities revealed to, and reconciled by, him in the process.

Using his novel as a starting point, my paper will first describe the uses of pseudotranslation in literary fiction by writers wishing to increase their publication chances, voice criticism of the source-language culture, or ride the wave of success originating from the source language prestige (Lefevere 1984).

Following on from Toury's (1995) reasoning that pseudo-translations often go to such great lengths to resemble genuine translations that a pseudo source text in a source language may be reconstructed from it, McCarthy (2004) says that if the translation creates the original, then the pseudo-translation also creates its pseudo-original. Consequently, the pseudo-references to the culture from which this translation purports to come will recreate this culture, which will have as much substance for the target literature as that of genuine translations.

In that context, the challenges pseudo-translations pose to translators will be explored. Instead of dealing with a text only once removed from the target culture and language, they have to grapple with pseudo-cultures and sometimes even pseudolanguages twice removed.

Hence, I will revisit the dichotomies of overt-covert/foreignising-domesticating translation as potential strategies, and evaluate not only target language texts, but also screen adaptations of works of fiction using pseudo-translation by, for example, Akhundov, Vian and Makine.

Iris Guske is the Academic Director of the Kempten School of Translation \& Interpreting Studies, with applied linguistics and intercultural communication at the heart of her teaching and professional activities. Her major research interests are socio-/psycholinguistics and developmental psychology. She has published books and articles about German-Jewish child refugees, nonprofessional language mediation as well as experiential learning, and has co-edited books on global educational issues. 